\title{
Perception and risk management strategies for ranchers and their determinants: a case study from Turkey
}

\author{
Seyit Hayran ${ }^{*}$ (i) Murak Külekçi ${ }^{2}$ (D) Aykut Gül ${ }^{3}$ (D) \\ ${ }^{1}$ Department of Agricultural Economics, University of Cukurova, 01330, Adana, Turkey. E-mail: seyithayran@gmail.com. "Corresponding author. \\ ${ }^{2}$ Department of Agricultural Economics, Atatürk University, Erzurum, Turkey. \\ ${ }^{3}$ Department of Agricultural Economics, University of Cukurova, Adana, Turkey.
}

ABSTRACT: In this study, beef cattle farmers' perceptions of risk and risk management strategies, and their determinants were analyzed using factor analysis and partial least squares regression analysis. The data set used in this study came from a survey conducted in Erzurum Province. The results demonstrated that variability in fodder price, insufficient farm income, uncertainty in government policies were perceived as the most important risks. Clean cattle shelter, off-farm income, monitoring and preventing livestock diseases were perceived as the most important risk management strategies. Results, also, demonstrated that some characteristics of farmers affected farmers' perceptions. In this study, it was identified that the most important risk sources were economics-based. So, it was recommended that the government policy should be focused on preventing the fluctuations in input/output prices.

Key words: beef cattle farming, multivariate analysis, risk perception, risk management, Turkey.

Percepção e estratégias de gerenciamento de risco para fazendeiros e seus determinantes: um estudo de caso da Turquia

RESUMO: Neste estudo, as percepções dos pecuaristas de risco e estratégias de gestão de risco, e seus determinantes, foram analisados usando análise fatorial e análise de regressão de mínimos quadrados parciais. O conjunto de dados usado neste estudo veio de uma pesquisa realizada na província de Erzurum. Os resultados demonstraram que a variabilidade no preço da forragem, a renda agrícola insuficiente e a incerteza nas politicas governamentais foram percebidos como os riscos mais importantes. Abrigos para gado limpos, renda fora da fazenda, monitoramento e prevenção de doenças dos animais foram vistos como as estratégias de gestão de risco mais importantes. Os resultados, também, demonstraram que algumas características dos agricultores afetaram as percepções dos agricultores. Neste estudo, identificou-se que as fontes de risco mais importantes eram de base econômica. Assim, recomendou-se que a politica do governo fosse voltada para a prevenção das oscilações nos preços de insumos / produtos.

Palavras-chave: pecuária de corte, análise multivariada, percepção de risco, gerenciamento de risco, Turquia.

\section{INTRODUCTION}

Agricultural production is a basic and indispensable economic activity for human nutrition production. Adequate and balanced nutrition is important for the lives and well-being of individuals and accordingly for the development of society. Protein is an indispensable element in a balanced diet. Approximately $40-50 \%$ of individuals' daily protein needs must be met from proteins of animal origin (DINLER, 2014). The annual per capita consumption of red meat is $12.4 \mathrm{~kg}$ in Turkey in 2019 . This values are $26.99 \mathrm{~kg}$ and $10.31 \mathrm{~kg}$ in the USA and in the European Union (27 countries), respectively (OECD,
2019). This situation shows the need to increase the supply of animal products in Turkey. Livestock is a strategic subsector of agriculture because of the produce of animal products such as meat, milk, egg, etc. Beef cattle farming are economic activities that create employment opportunities for rural people, providing both demand (in terms of farm machinery and equipment) and raw material to industry, and the meeting the nutrition needs of the people. The level of consumption of animal products such as meat is considered one of the indicators which related to countries' development level. This is because of the importance of animal products in a person's daily diet. The consumption of animal products increases 
gradually in parallel with the social and economic development of countries. So, while developing technology and industrialization, the strategic importance of beef cattle farming increases in all countries.

Livestock farmers' perceptions of risk and risk management strategies have received attention in developed and developing economies. Especially, in Turkey, most of the studies about livestock has been the focus on dairy farming (AKCAOZ et al., 2009a; HAYRAN \& GÜL, 2015; ÖZSAYIN, 2019), beef cattle production did not receive attention from researchers. In the absence of studies, the knowledge about beef cattle farmers' perception of risk and risk management strategies, and the determinants of perceptions is not satisfactory. So, this study extends knowledge about livestock farmers' risk behavior by investigated beef cattle farmers' perception of risk and risk management strategies, and also this study revealed the determinants of farmers' perceptions in Erzurum Province of Turkey. At the end of the study, some recommendations suggested to policymakers concerned with the development of beef cattle production in a developing country such as Turkey.

The main reason for the selection of Erzurum as a research area is that Erzurum is one of Turkey's most prominent provinces in terms of beef cattle farming. The shares of Erzurum in Turkey's total number of cattle are $4.64 \%$ in 2019 (TÜİK, 2020). Erzurum, in terms of total cattle, is Turkey's second-largest province. However, this ratio does not state the real animal presence of Erzurum because a significant proportion of cattle are sold to traders from other provinces to meet the needs of other provinces. Beef cattle farming are the main livelihood source of people in Erzurum, because of both the climate and the geographical structure being very suitable.

The rest of the study was organized as follows: Section 2 deals with materials and methods; Section 3 presented a discussion of the results, and Section 4 presented conclusions.

\section{MATERIALS AND METHODS}

\section{Research area and data}

Erzurum province counts for $3.20 \%$ of the total surface area of Turkey. The area that Erzurum covers is $25066 \mathrm{~km}^{2}$. Thirty percent of the total area is in the Black Sea Region and 70\% is in the Eastern Anatolia Region. Erzurum is located

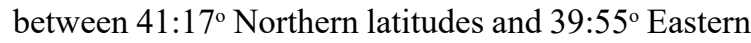
longitudes. The Erzurum Province is divided into 20 districts. The annual amount of precipitation is 453.00 $\mathrm{mm}$, and there are not significant differences between seasons. The average temperature of the province is $5.7{ }^{\circ} \mathrm{C}$ in a year (ANONYMOUS, 2020). According to the report of the 2019 population census, the total size of the Erzurum population was 762062 people in 2019 . Of this population, $49.85 \%$ was male and $50.15 \%$ was female. Erzurum is the fourth largest province in terms of Turkey area. However, the population density is quite low (30 People $/ 1 \mathrm{~km}^{2}$ ) (TÜİK, 2020).

The data used in the study obtained from the cross-sectional survey conducted in Erzurum Province. The main household survey was conducted face-to-face with farmers during the period of January and February of 2020 to obtain research data in Erzurum. 120 randomly selected farmers, determined by a simple random sampling method, were visited to obtain research data. The four districts (Ispir, Çat, Pasinler and Askale) located in the North, in the South, in the East and in the West of Erzurum province, and four villages each from these four districts where beef cattle farming is intensely carried out had determined to select the sample farms that can represent Erzurum province in terms of beef cattle farming. The number of farms in these villages constituted the population size. The total number of farms in the population was determined as 704 . The number of sample farms to be surveyed was determined with the following formula according to the simple random sampling method (YAMANE, 1967).

$$
n=\frac{N \cdot \sigma^{2}}{(N-1) D+\sigma^{2}}=109.74
$$

$n=109.74$

$\mathrm{n}=$ Number of farms to be surveyed,

$\mathrm{N}=$ Number of farms in the population,

$\sigma^{2}=$ The variance of the number of cattle owned by the farms in the population,

$\mathrm{D}=\left(\mathrm{d}^{2} / \mathrm{z}^{2}\right)$ value;

$\mathrm{d}=$ the margin of error of the difference between the sample mean and the population mean,

$\mathrm{Z}=\mathrm{z}$ value in the Standard Normal Distribution table according to the error rate.

The number of surveys reported was increased by $10 \%$, and the total number of sample farms was determined as 120 . After the sample farms was determined, the sample villages were visited, and the questionnaire forms were filled with the face-toface interviews with the farmers. In the distribution of the total sample farms by districts, the number of farms in the districts was taken into account. In this study, $5 \%$ and $95 \%$ was accepted as the margin of error and the reliability limit, respectively. 
A structured questionnaire was used for the data collection instrument. The questionnaire consisted of information on farms' and farmers' characteristics and risk perceptions. Information on farmers' risk and risk management strategies were gathered using a Likert-type five-point ordinal scale questions were prepared to take into account the previous studies about risk and risk management strategies (BISHU et al., 2018; HAYRAN \& GÜL, 2015; LITRE \& BURSZTYN, 2015; MERANER \& FINGER, 2019; MEUWISSEN et al., 1999; MEUWISSEN et al., 2001), studies about livestock in the province of Erzurum (ALBEZ, 2018; ŞANAL, 2013; ÜNAL, 2004) and the socioeconomic, political, and environmental conditions of agriculture in the region (ANONYMOUS, 2014, 2020). After the scales of risk and risk management strategies were prepared, they were reorganized as a result of interviews with agricultural engineers, veterinarians and leader farmers in the Erzurum, and the final scales were prepared. In order to analysis farmers' risk and risk management strategies perception, they were asked to indicate the degree of their agreement on each items using a Likerttype five-point ordinal scale of Entirely Agree, Agree, Moderate Agree, Disagree and Entirely Disagree with appointing a weight of 5, 4, 3, 2 and 1 for all risk sources and risk management strategies.

\section{Data analysis}

In this study, mean and standard deviation, principal components analysis (PCA), and partial least squares multiple regression (PLS) were used as statistical analysis methods (ALPAR, 2011; GREENE, 1997; HAIR et al., 1994). Also, descriptive statistics were used to define the characteristics of sample farms and farmers and to determine the importance of risk sources and risk management strategies.

PCA was used to gather various risk sources and risk management strategies under smaller number of components. Factors were assessed with eigenvalues greater than 1 and varimax rotation was used. Prior to PCA, the Kaiser-Meyer-Olkin measure of sampling adequacy (KMO) and Bartlett's Test of Sphericity were used to verify the risk and risk management strategies scales suitable for the PCA (HAIR et al., 1994; KALAYCI, 2008; ÜNVER \& GAMGAM, 2008). The KMO values of 0.808 and 0.662 for risk sources and risk management strategies scale, respectively. Bartlett's Tests of Sphericity were significant at $p$-values $<0.000$ for two scales. These values verified that both the risk sources and the risk management strategies scales were suitable for the PCA. Cronbach's alpha was used in order to check the internal reliability of scales (CRONBACH, 1951). The Cronbach's alpha values were 0.868 and 0.639 for risk source and risk management strategies scales, respectively.

The partial least squares multiple regression (PLS) was used for estimating the coefficients related to the relationship between socioeconomic variables (Table 1), and factor scores derived from the PCA were used as dependent variables. The variance inflation factors for all variables used in regression analysis were between 1.066 and 1.446, and all tolerance values were greater than 0.2 . These results verified that multicollinearity was not issue (GUJARATI, 2009). Results of the Breusch-Pagan test showed that heteroskedasticity was not a problem for variables (BREUSCH \& PAGAN, 1979).

Table1 - Independent variables used in regression analysis.

\begin{tabular}{|c|c|c|c|c|c|}
\hline Independent Variables & Description & Min & Max & Mean & $\mathrm{SD}$ \\
\hline Education & $\begin{array}{l}\text { Farmers' education level (Primary school 1; Secondary school 2; } \\
\text { High school 3; University 4) }\end{array}$ & 1.00 & 4.00 & 1.98 & 1.06 \\
\hline Family Size & Household size as person & 2.00 & 12.00 & 5.59 & 1.67 \\
\hline Experience & Farmers' livestock experience as year & 3.00 & 55.00 & 22.30 & 11.43 \\
\hline Off-Farm Income & If the farmer has an off-farm income source 1 ; Other 0 & 0.00 & 1.00 & 0.55 & 0.50 \\
\hline Growing forage crops & If the farmer produces forage crops 1 ; Other 0 & 0.00 & 1.00 & 0.83 & 0.37 \\
\hline Land Size (ha) & Agricultural land size as ha & 0.00 & 130.00 & 11.14 & 14.37 \\
\hline Number of cattle & Cattle size & 6.00 & 200.00 & 32.55 & 32.91 \\
\hline Extension & $\begin{array}{c}\text { Frequency of the farmer's meeting with the extension staff } \\
\text { (Never } 0 ; \text { Few times a year } 1 \text {; Few times a month } 2 \text {; Few times a } \\
\text { week } 3 \text { ) }\end{array}$ & 0.00 & 3.00 & 1.10 & 0.63 \\
\hline
\end{tabular}

Ciência Rural, v.51, n.6, 2021. 


\section{RESULTS AND DISCUSSION}

\section{Some characteristics of farms and farmers}

Farmers' ages ranged from 20 to 75 and the mean age was 44.02 years (SD: 11.56). The education level of the farmers was not satisfactory. $46.70 \%$ of farmers were primary school graduates. The proportion of farmers had middle and high school graduates were $20.00 \%$ and $22.50 \%$, respectively. $10.80 \%$ of the farmers were university graduates. The mean family size was 5.59 people (SD: 1.67 ). $55.00 \%$ of sample farmers had an off-farm income source. $9.17 \%$ of the farmers stated that they had never met with the extension staff during beef cattle farming activities. While most of the farmers $(77.50 \%)$ met with agricultural extension staff a few times a year, $7.50 \%$ met a few times a month, and $5.83 \%$ a few times a week. $83.00 \%$ of all farmers produced forage crops in addition to beef cattle farming. The mean agricultural land of farmers was 11.14 ha (14.37), and the mean cattle asset was 32.55 (SD: 32.91 ).

\section{Farmers' perception and its determinants regarding} risk sources

The descriptive statistics such as mean values and standard deviations on risk sources scale presented in table 2. Variability in fodder price, insufficient farm income and uncertainty

Table 2 - Descriptive statistics and factor loadings scores for the risk sources

\begin{tabular}{|c|c|c|c|c|c|c|c|c|}
\hline \multirow[t]{2}{*}{ Risk Sources } & \multirow[t]{2}{*}{ Mean } & \multirow[t]{2}{*}{ SD } & \multicolumn{6}{|c|}{ 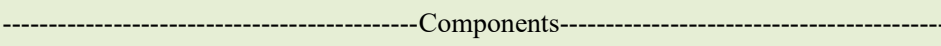 } \\
\hline & & & 1 & 2 & 3 & 4 & 5 & 6 \\
\hline Variability in fodder price & 4.43 & 0.92 & -0.055 & -0.219 & 0.057 & 0.135 & 0.697 & -0.125 \\
\hline Insufficient farm income & 4.28 & 1.00 & 0.312 & 0.264 & 0.505 & -0.067 & 0.494 & 0.053 \\
\hline $\begin{array}{l}\text { Uncertainty in government } \\
\text { policies }\end{array}$ & 4.01 & 1.16 & 0.734 & 0.067 & 0.227 & 0.081 & 0.305 & 0.139 \\
\hline Cash shortage & 3.93 & 1.11 & 0.460 & -0.054 & 0.733 & 0.057 & 0.018 & 0.010 \\
\hline Problems in marketing & 3.93 & 1.08 & 0.282 & 0.042 & 0.131 & -0.019 & 0.563 & 0.148 \\
\hline High interest rate & 3.77 & 1.41 & 0.263 & 0.029 & 0.778 & 0.006 & 0.007 & 0.171 \\
\hline $\begin{array}{l}\text { Risk of losing key } \\
\text { employees }\end{array}$ & 3.73 & 1.27 & 0.244 & 0.228 & 0.186 & 0.041 & -0.036 & 0.702 \\
\hline $\begin{array}{l}\text { Inadequate farmers } \\
\text { organization }\end{array}$ & 3.72 & 1.39 & 0.527 & 0.230 & 0.417 & -0.041 & 0.182 & 0.306 \\
\hline Variability in meat price & 3.71 & 1.25 & 0.719 & 0.131 & 0.070 & 0.233 & 0.021 & 0.156 \\
\hline Lack of savings & 3.68 & 1.28 & 0.778 & 0.025 & 0.277 & 0.001 & 0.039 & 0.100 \\
\hline $\begin{array}{l}\text { Difficulties in obtaining } \\
\text { calves for fattening }\end{array}$ & 3.60 & 1.29 & 0.329 & 0.490 & 0.173 & 0.296 & 0.302 & 0.171 \\
\hline Forage shortage & 3.57 & 1.26 & 0.168 & 0.617 & -0.031 & -0.204 & 0.256 & -0.065 \\
\hline High labor costs & 3.53 & 1.35 & 0.067 & 0.103 & 0.650 & 0.211 & 0.136 & 0.447 \\
\hline Shepherd shortage & 3.51 & 1.36 & 0.265 & 0.193 & 0.146 & 0.533 & 0.339 & 0.240 \\
\hline Shortage of family labor & 3.41 & 1.13 & 0.139 & -0.074 & -0.039 & 0.711 & 0.082 & -0.065 \\
\hline $\begin{array}{l}\text { Insufficiency in barn } \\
\text { capacity }\end{array}$ & 3.33 & 1.42 & 0.021 & 0.098 & 0.560 & 0.464 & 0.158 & -0.450 \\
\hline Family relationships & 3.15 & 1.50 & 0.774 & -0.052 & 0.113 & 0.100 & -0.041 & 0.024 \\
\hline Difficulties in finding labor & 3.12 & 1.29 & 0.393 & -0.048 & 0.226 & 0.375 & 0.154 & 0.562 \\
\hline $\begin{array}{l}\text { Technical failure } \\
\text { (machinery, equipment) }\end{array}$ & 2.58 & 1.38 & 0.044 & 0.240 & 0.117 & 0.617 & -0.111 & 0.151 \\
\hline $\begin{array}{l}\text { Epidemic livestock } \\
\text { diseases }\end{array}$ & 2.51 & 1.28 & -0.064 & 0.713 & -0.010 & 0.419 & -0.193 & 0.094 \\
\hline $\begin{array}{l}\text { Non-Epidemic livestock } \\
\text { disease }\end{array}$ & 2.48 & 1.29 & -0.149 & 0.723 & 0.124 & 0.317 & -0.157 & 0.121 \\
\hline High animal mortality rate & 2.48 & 1.24 & -0.022 & 0.720 & 0.041 & -0.006 & 0.025 & 0.171 \\
\hline Cattle accident & 2.38 & 1.33 & 0.107 & 0.555 & 0.154 & 0.019 & -0.498 & 0.009 \\
\hline Livestock pests & 2.21 & 1.24 & 0.381 & 0.631 & -0.030 & -0.009 & -0.376 & -0.190 \\
\hline $\begin{array}{l}\text { Total variance explained } \\
\text { (TVE) }(\%)\end{array}$ & & & 15.115 & 13.553 & 11.119 & 8.656 & 8.287 & 6.814 \\
\hline Cumulative TVE (\%) & & & 15.115 & 28.668 & 39.787 & 48.443 & 56.729 & 63.543 \\
\hline
\end{tabular}


in government policies were the most important three risk sources in terms of farmers' perception. GÖKGÖZ (2018) reported that fluctuation in input and output prices, epidemic livestock disease, and the possibility of the main staff leaving the job were the major risk sources in the Aegean region of Turkey. The study by HALL et al, (2003) reported that drought, variability in the forage price, and livestock diseases as the major risk sources according to beef cattle producers' perceptions in Texas and Nebraska of the USA. The shortage of family labor, the high price of fodder, and small farm income were identified as the top-rated three risk sources in the rural Tigray region of Northern Ethiopia (BISHU et al., 2018). A study on the Dutch livestock farmers reported that meat prices and epidemic animal disease were perceived as the major risk sources (MEUWISSEN et al., 2001). As general consequences of our findings compared with similar studies; it can be said that level/fluctuation in the input/output price, epidemic diseases, and the small farm income were the most relevant risk sources according to farmers' perception in the beef cattle farming, the irrespective of the country where the studies are conducted.

A factor analysis run on the risk sources scale; six factors, their respective factor loadings, and the rate of explained variance are presented in table 2. The six factors were identified, based on their loadings, were labeled as institutional and output price risk, production risk, financial risk, labor shortage and technical risk, input price and marketing risk, and labor risk.

Factor 1, institutional and output price risk, loaded significantly on uncertainty in government policies, inadequate farmers' organization, variability in meat price, lack of savings, family relationships. In a study conducted on the wheat farmers in Turkey, in accordance with our findings, uncertainty in government policies, output prices, lack of savings, and family relationships has reported significant sources of risk (HAYRAN, 2019). Factor 2 , production risk, has high loadings on difficulties in obtaining calves for fattening, forage shortage, epidemic and non-epidemic livestock disease, high animal mortality rate, cattle accident, livestock pests. Difficulties in providing calves for fattening are related to both calf storage and calf prices. In a study conducted in Turkey, it has reported that calves purchasing cost consisted of $52.57 \%$ of total variable costs in beef cattle production (AĞIR \& AKBAY, 2017). A study by BENNETT (2003) in Great Britain stated that the presence of animal disease means that the farmers operated at the low production frontier and, both output losses and the use of additional inputs and thus a waste of resources (BENNETT, 2003). The animal mortality rate was an important concern in the research area. In a study conducted in the USA, it has been reported that decreasing animal mortality rates in hog production as an example, will lead to an improvement both in producer and consumer surplus (OTT et al., 1995). The factor 3, financial risk, has high loading on insufficient farm income, cash shortage, high interest rate, high labor costs, and insufficiency in the capacity of the barn. These sources of risk reported to be the most important in some previous studies conducted in different braches of agriculture and in different countries, also (FLATEN et al., 2005; HAYRAN \& GÜL, 2015; MEUWISSEN et al., 2001). Factor 4, labor shortage and technical risk, has high loadings on difficulties in find shepherd, shortage of family labor, technical failure. Factor 5, input price and marketing risk, has high loadings on variability in fodder price and problems in marketing. Approximately $30 \%$ of the total costs consist of fodder costs in Turkey (CELIK \& SARIÖZKAN, 2017; GÖZENER \& SAYILI, 2015). This ratio indicated the importance of fodder costs for farmers. Factor 6, labor risk, has high loadings on risk of losing key employees and difficulties in find labor.

PLS regression analysis was run, using factor scores as dependent variables derived from PCA, to investigate the relationship between farmers' risk perception and some characteristics of farms and farmers. The description of independent variables and their descriptive statistics are present in table 1 . Results of regression analysis are presented in table 3. The variables with VIP (Variable importance in Projection) value higher than or equal to 1.00 are discussed (AKARACHANTACHOTE, et al. 2014).

Results showed that the farmers' education level was positively and significantly related to institutional and output price risk, and labor risk. These findings lined with KISAKA-LWAYO \& OBI (2012). Farmers with larger family size perceived production risk to be more important compared to those with smaller families. Dealing with production risks is costly. Farmers with large family sizes, maybe have difficulties in meeting this cost in addition to family expenses in the research area. This finding lined with AHMAD et al (2019) which reported that a positive relationship between family size and farmers' perception of wheat diseases in Pakistan. Farmers with a high number of cattle perceived institutional and output price risk, and input price and marketing risk as more important. And also, farmers with a high number of cattle perceived input/ 
Table 3 - PLS regression analysis results for the risk sources, $n=120$.

\begin{tabular}{|c|c|c|c|c|c|c|c|c|c|c|c|c|}
\hline \multirow[t]{3}{*}{ Variable } & \multicolumn{12}{|c|}{ 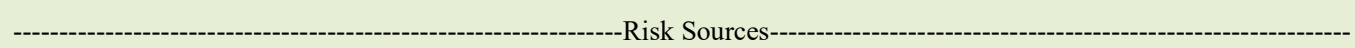 } \\
\hline & \multicolumn{2}{|c|}{$\begin{array}{c}\text { Institutional and } \\
\text { Output Price } \\
\text { Risk }\end{array}$} & \multicolumn{2}{|c|}{ Production Risk } & \multicolumn{2}{|c|}{ Financial Risk } & \multicolumn{2}{|c|}{$\begin{array}{c}\text { Labor Shortage } \\
\text { and Technical } \\
\text { Risk }\end{array}$} & \multicolumn{2}{|c|}{$\begin{array}{l}\text { Input Price and } \\
\text { Marketing Risk }\end{array}$} & \multicolumn{2}{|c|}{ Labor Risk } \\
\hline & VIP & Coef. & VIP & Coef. & VIP & Coef. & VIP & Coef. & VIP & Coef. & VIP & Coef. \\
\hline Education & 1.434 & 0.203 & 0.537 & -0.063 & 0.092 & -0.009 & 0.999 & -0.091 & 0.323 & -0.042 & 1.038 & 0.140 \\
\hline $\begin{array}{l}\text { Number of } \\
\text { cattle }\end{array}$ & 1.196 & 0.131 & 0.112 & -0.013 & 0.928 & -0.093 & 0.623 & -0.057 & 1.479 & 0.194 & 0.823 & 0.111 \\
\hline Experience & 0.982 & -0.139 & 0.484 & -0.057 & 1.979 & -0.199 & 1.439 & 0.130 & 0.806 & 0.106 & 0.140 & -0.019 \\
\hline $\begin{array}{l}\text { Growing } \\
\text { forage crops }\end{array}$ & 0.957 & 0.087 & 0.841 & -0.100 & 1.032 & -0.104 & 0.725 & -0.066 & 0.333 & 0.044 & 1.298 & 0.175 \\
\hline Family Size & 0.928 & 0.135 & 2.093 & 0.248 & 0.543 & -0.055 & 0.114 & 0.010 & 0.677 & -0.089 & 0.966 & 0.130 \\
\hline $\begin{array}{l}\text { Land Size } \\
\text { (ha) }\end{array}$ & 0.623 & -0.088 & 0.317 & -0.038 & 1.238 & -0.125 & 1.322 & -0.120 & 0.214 & -0.028 & 0.624 & 0.084 \\
\hline $\begin{array}{l}\text { Off-Farm } \\
\text { Income }\end{array}$ & 0.618 & 0.169 & 0.022 & 0.003 & 0.530 & -0.053 & 1.496 & -0.136 & 1.793 & -0.236 & 1.749 & 0.235 \\
\hline Extension & 0.532 & 0.029 & 1.508 & -0.178 & 0.207 & 0.021 & 0.143 & 0.013 & 1.109 & -0.146 & 0.399 & 0.054 \\
\hline $\mathrm{R}^{2}$ & \multicolumn{2}{|c|}{------0.147------- } & \multicolumn{2}{|c|}{-------0.120------ } & \multicolumn{2}{|c|}{-------0.123------- } & \multicolumn{2}{|c|}{------0.089-------- } & \multicolumn{2}{|c|}{------0.141-------- } & \multicolumn{2}{|c|}{-------0.196-------- } \\
\hline Std. deviation & \multicolumn{2}{|c|}{------0.928------- } & \multicolumn{2}{|c|}{-------0.942------ } & \multicolumn{2}{|c|}{-------0.940------ } & \multicolumn{2}{|c|}{------0.959------- } & \multicolumn{2}{|c|}{------0.931-------- } & \multicolumn{2}{|c|}{-------0.900------- } \\
\hline MSE & \multicolumn{2}{|c|}{------0.846------- } & \multicolumn{2}{|c|}{-------0.873------- } & \multicolumn{2}{|c|}{-------0.870------ } & \multicolumn{2}{|c|}{------0.904------- } & \multicolumn{2}{|c|}{------0.852------- } & \multicolumn{2}{|c|}{-------0.797-------- } \\
\hline RMSE & \multicolumn{2}{|c|}{------0.920------- } & \multicolumn{2}{|c|}{-------0.934------ } & \multicolumn{2}{|c|}{-------0.933------ } & \multicolumn{2}{|c|}{------0.951-------- } & \multicolumn{2}{|c|}{------0.923------- } & \multicolumn{2}{|c|}{------0.893------ } \\
\hline
\end{tabular}

Note: Standardized coefficients were presented, VIP: Variable Importance in Projection.

output price and marketing risk as more important than their colleagues with a small number of cattle. Farmers with more numbers of cattle need much more forage and other inputs, and also they sell much more amount of living animals and beef. So, these farmers are more influenced by variability in prices. This finding is contradicted with BISHU et al (2018), who reported farmers with a high number of cattle perceived price variability included in the market risk as less important. Financial risk was less important in terms of the perceptions of farmers with high agricultural experience.

According to this finding, less experienced farmers considered that financial risk to be a major concern for their farms. Another important finding stated that more experienced farmers considered that labor shortage and technical risk more important. Farmers who had off-farm income sources perceived labor shortage and technical risk, and input price and marketing risk less important; however, they perceived labor risk more important. This finding lined with AHMAD et al (2019) which reported that a negative relationship between offfarm income and farmers' perception of price risk in Pakistan. Our results also revealed that farmers who grown forage crops tend to perceive a higher labor risk, probably due to the fact that growing forage crops need more labor. Farmers producing forage crops perceive the input price risk less important. The main reason for this may be that farmers who producing forage crops, which is the most expensive input in beef cattle farming, maybe less affected by the fluctuation in input prices.

Our finding revealed that farmers with larger agricultural land perceive financial risk less important, but labor shortage and technical risk more important. This finding is contradicted with NADEZDA et al (2017) which reported a positive coefficient between land size and price risk perception. In our study, the main reason for the low perception of output price risk by farmers with large agricultural land may be have the facility to growing forage crops to meet their farms' needs. So, farmers with large agricultural land are less affected by variability in meat prices. In our study, production risk included difficulties in calves for fattening, forage shortage, epidemic and non-epidemic livestock disease, high animal mortality rate, cattle accident, livestock pests. Farmers who use agricultural extension services may have the ability to cope with such risks with the knowledge and information they have acquired through these services. Important research findings 
revealed that farmers who used agricultural extension services perceived production risks and input price and marketing risk less important.

\section{Farmers' perception and its determinants regarding risk management strategies}

The descriptive statistics such as mean values and standard deviations on risk management scale are presented in table 4 . Clean cattle shelter, offfarm income, monitoring and preventing livestock disease, crop production was determined to be the most important risk management strategies in terms of farmers' perception. The study by HALL et al. (2003) reported that understocking pasture and storing hay as the major risk management strategies according to beef cattle producers' perceptions in Texas and Nebraska of the USA. Use of veterinary services, parasite control, loan allocation, and disease prevention were identified as the top-rated risk management strategies in the rural Tigray region of Northern Ethiopia (BISHU et al.., 2018). A study on the Dutch livestock farmers reported that producing at lowest possible costs, buying business/personal insurance, applying strict hygienic rules were perceived as the major risk management strategies (MEUWISSEN et al., 2001). As general consequences of our findings compared with similar studies; it can be said that disease control using veterinary services, parasite control etc. the most important risk management strategy in terms of farmers' perception.

Afactor analysis run on the risk management strategies scale; four factors, their respective factor loadings, and the rate of explained variance are presented in table 4 . The four factors, based on their loadings, were labeled as disease control, agricultural credit and organization, income diversification and planning, agricultural diversification.

Risk management strategies contained by the first factor were discussed in the previous paragraph. The second factor had high loadings on agricultural credit, cooperative partnership, contract farming. So, this factor labeled as agricultural credit and organization. These findings lined with E SAQIB et al. (2016) which focus on agricultural credit as a risk management strategy, and with MEUWISSEN et al. (2001) which defined contract agriculture as an effective risk management strategy, and with AHSAN (2011) which reported that cooperative marketing is an effective risk management strategy. In agriculture, especially in livestock, farmers can obtain gain one or a few times depending on animals coming to slaughter age.

However, farmers need cash money or credit to meet their farms' current needs. In the research area, agricultural credit was defined as one of the most effective risk management tools for livestock farmers. So, it is necessary to investigate beef cattle farmers' accessibility in credit services and to identify the main constraints in Erzurum. Well-designed financial policy and institutions might help farmers to cope with the current and potential risks. In a study conducted in Turkey, sample farmers expressed that they used cooperatives to obtained technical information, to purchase input, and to use credit in the beef cattle production. But, they stated that the facilities of the cooperative not enough

Table 4 - Descriptive statistics and factor loadings scores for the risk management strategies.

\begin{tabular}{|c|c|c|c|c|c|c|}
\hline \multirow[t]{2}{*}{ Risk Management Strategies } & \multirow[t]{2}{*}{ Mean } & \multirow[t]{2}{*}{$\mathrm{SD}$} & \multicolumn{4}{|c|}{ 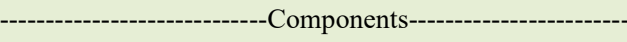 } \\
\hline & & & 1 & 2 & 3 & 4 \\
\hline Clean cattle shelter & 4.53 & 0.70 & 0.729 & -0.333 & -0.04 & -0.001 \\
\hline Off-farm income & 4.10 & 1.02 & 0.155 & 0.192 & 0.648 & -0.227 \\
\hline Monitoring and preventing livestock disease & 3.98 & 0.95 & 0.739 & 0.167 & -0.028 & -0.154 \\
\hline Agricultural diversification & 3.97 & 1.06 & 0.095 & -0.099 & 0.123 & 0.827 \\
\hline Planning of expenditures & 3.97 & 1.19 & 0.179 & 0.136 & 0.791 & 0.167 \\
\hline Use of veterinary services & 3.90 & 1.16 & 0.664 & 0.12 & 0.144 & 0.232 \\
\hline Parasite control & 3.75 & 1.12 & 0.691 & 0.234 & 0.257 & 0.098 \\
\hline Separate cattle pen & 2.68 & 1.45 & -0.078 & -0.116 & 0.705 & 0.232 \\
\hline Agricultural credit & 2.58 & 1.41 & -0.006 & 0.707 & 0.046 & 0.483 \\
\hline Cooperative partnership & 2.57 & 1.23 & 0.015 & 0.665 & 0.224 & -0.123 \\
\hline Contract farming & 2.03 & 1.16 & 0.202 & 0.801 & -0.073 & -0.15 \\
\hline Total variance explained (TVE) (\%) & & & 19.168 & 17.008 & 15.500 & 10.684 \\
\hline Cumulative TVE (\%) & & & 19.168 & 36.176 & 51.677 & 62.361 \\
\hline
\end{tabular}


for marketing and training (ÖZ \& KIZILASLAN, 2019). So, the cooperative partnership might provide the opportunity to effectively use multiple risk management strategies to the farmers. The third factor, income diversification and planning, had high loading on off-farm income, planning of expenditures, separate cattle pen. The fourth factor consists of only one strategy; Agricultural diversification. Agricultural diversification means that any farmer engages one or more agricultural activities in addition to the main agricultural activity (WHITE \& BLACK, 2002). In this case, it means that the farmer engages crop production in addition to beef cattle production. This finding compatible with MEUWISSEN et al. (2001) which identified diversification as a risk management strategy in the case of Dutch livestock farmers.

Results of the PLS regression analysis conducted to investigate the relationship between farmers' perceptions of risk management strategies and some characteristics of farms and farmers are presented in table 5. Factor scores derived from PCA was used as a dependent variable in the regression analysis. The description of independent variables and their descriptive statistics are present in table 1. The results of regression analysis are presented in table 5. The variables with VIP (Variable importance in Projection) value higher than or equal to 1.00 are discussed (AKARACHANTACHOTE, et al. 2014).

More educated farmers perceived the disease control strategy as more important than their other colleagues. Also, the disease control strategy was perceived as more important by farmers who have larger number of cattle. Moreover, farmers who use the agricultural extension service attached more importance to the disease control strategy than their other colleagues. Another research finding showed that the agricultural credit and organizational strategy was determined by some characteristics of the farmers. The relationship between farmers' agricultural experience and the level of importance they attribute to the agricultural credit and organizational strategy had a negative coefficient. This finding indicated that farmers with less agricultural experience attached more importance to agricultural credit and organization strategy. Farmers with a larger family size perceived the agricultural credit and organizational strategy as more important. Farmers who use agricultural extension services perceived the agricultural credit and organization strategy as more important than their other colleagues. In addition, agricultural credit and organization strategy was perceived as more important by farmers with off-farm income sources. Income diversification and planning strategy was perceived as less important by farmers with the more agricultural experience. Also, farmers with larger agricultural land attached less importance on income diversification and planning strategy. Agricultural diversification, another important risk management strategy, was perceived as more important by farmers who had large number of cattle. Farmers producing

Table 5 - PLS regression analysis results for the risk management strategies, $\mathrm{n}=120$.

\begin{tabular}{|c|c|c|c|c|c|c|c|c|}
\hline \multirow[t]{3}{*}{ Variable } & \multicolumn{8}{|c|}{ 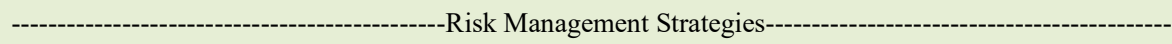 } \\
\hline & \multicolumn{2}{|c|}{----Disease Control--- } & \multicolumn{2}{|c|}{$\begin{array}{l}\text { Agricultural Credit and } \\
\text { Organization }\end{array}$} & \multicolumn{2}{|c|}{$\begin{array}{l}\text { Income Diversification } \\
\text { and Planning }\end{array}$} & \multicolumn{2}{|c|}{$\begin{array}{c}\text { Agricultural } \\
\text { Diversification }\end{array}$} \\
\hline & VIP & Coef. & VIP & Coef. & VIP & Coef. & VIP & Coef. \\
\hline Education & 1.053 & 0.109 & 0.787 & 0.113 & 0.628 & 0.056 & 0.917 & 0.112 \\
\hline Number of cattle & 1.789 & 0.185 & 0.187 & -0.027 & 0.253 & 0.023 & 1.072 & 0.131 \\
\hline Experience & 0.578 & -0.060 & 1.604 & -0.230 & 1.670 & -0.149 & 0.325 & 0.040 \\
\hline Growing forage crops & 0.935 & 0.097 & 0.622 & 0.089 & 0.861 & -0.077 & 1.263 & 0.154 \\
\hline Family Size & 0.507 & -0.053 & 1.017 & 0.146 & 0.181 & 0.016 & 0.243 & 0.030 \\
\hline Land Size (ha) & 0.183 & -0.019 & 0.538 & 0.077 & 1.919 & -0.171 & 1.381 & 0.168 \\
\hline Off-Farm Income & 0.751 & 0.078 & 1.288 & 0.185 & 0.499 & -0.044 & 1.281 & 0.156 \\
\hline Extension & 1.277 & 0.132 & 1.184 & 0.170 & 0.216 & 0.019 & 0.839 & 0.102 \\
\hline $\mathrm{R}^{2}$ & \multicolumn{2}{|c|}{---------0.086-------- } & \multicolumn{2}{|c|}{-----------0.196---------- } & \multicolumn{2}{|c|}{ 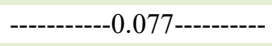 } & \multicolumn{2}{|c|}{---------0.173--------- } \\
\hline Std. deviation & \multicolumn{2}{|c|}{----------0.960--------- } & \multicolumn{2}{|c|}{------------0.901----------- } & \multicolumn{2}{|c|}{-----------0.965---------- } & \multicolumn{2}{|c|}{----------0.913---------- } \\
\hline MSE & \multicolumn{2}{|c|}{----------0.907--------- } & \multicolumn{2}{|c|}{------------0.798----------- } & \multicolumn{2}{|c|}{ 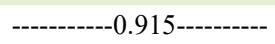 } & \multicolumn{2}{|c|}{----------0.820---------- } \\
\hline RMSE & \multicolumn{2}{|c|}{----------0.952--------- } & \multicolumn{2}{|c|}{------------0.893----------- } & \multicolumn{2}{|c|}{-----------0.957---------- } & \multicolumn{2}{|c|}{----------0.906---------. } \\
\hline
\end{tabular}

Note: Standardized coefficients were presented, VIP: Variable Importance in Projection. 
forage crops attached more importance to the agricultural diversification strategy than their other colleagues. Farmers with larger agricultural land, and farmers with off-farm income sources perceived the agricultural diversification strategy more importantly.

\section{CONCLUSION}

In this study, investigated beef cattle farmers' perception of risk and risk management strategies in Turkey based on a case study conducted in Erzurum Province. The mix statistical techniques were used consisted of descriptive statistics, factor analysis (PCA), and multiple regression analysis. This study contributed to the growing literature analyzing cattle farmers' risk perception in developing economies such as Turkey. Variability in fodder price, insufficient farm income, uncertainty in government policies, and cash shortage perceived as the most important risk sources by beef cattle farmers. In this study, it was identified that the most important risk sources were economics-based as similar to studies in vegetal production and dairy farming (AĞIR et al., 2015; AKCAOZ et al., 2009a, 2010; AKCAOZ et al., 2009b; HAYRAN, 2019; HAYRAN $\&$ GÜL, 2015). So, it was recommended that the government policy should be focused on preventing the fluctuations in input/output prices. The main reason for the price fluctuation is due to the amount of production; and therefore, the fluctuations in the amount of supply. The fluctuations in the amount of supply are caused by input costs, in other words, fluctuations in input prices and low productivity. In this respect, input subsidies and the organization to be made between farmers can provide inputs more cheaply. The organization also creates advantageous market conditions for the farmers to obtain better marketing opportunity. The use of modern techniques in production may lead to an increase in productivity, and to a decrease in input costs and an increase in production. In our study clean cattle shelter, off-farm income, monitoring and preventing livestock disease, and agricultural diversification were perceived as the most important risk management strategies. The relationships between farmers' perception regarding risk and risk management strategies and some characteristics of farms and farmers were investigated using multiple regression analysis. The results of regression analysis indicated that some characteristics of farms and farmers had significant influences on farmers' perception regarding risk and risk management strategies. The goodness-of-fit was low in the models. These low levels of goodness-of- fit maybe because of very personal perception and/or that some variables which have a potential influence on a farmer's perceptions have not included in the model. However, previous studies on risk perception also observed the same situations (BISHU et al., 2018; HAYRAN, 2019; MEUWISSEN et al., 2001). We recommend that considering the results of the research in the policies design to develop beef cattle production and to improve the welfare of farmers. Research results revealed that farmers' perceptions did not homogeneous and were influenced by some socioeconomic variables. Accordingly, the agricultural risk management policies to be developed should also be multi-tailed. Further researches are necessary in order to understand how different social groups respond to risk, especially on gender lines. And also, more future research is necessary to investigate the effect of the COVID-19 pandemic on farmers' risk behaviors and how it shapes them.

\section{ACKNOWLEDGEMENTS}

This study was not supported by any institution. We would like to thank the farmers who patiently answered us in the survey applications.

\section{DECLARATION OF CONFLICT OF INTERESTS}

The authors declare no conflict of interest. The founding sponsors had no role in the design of the study; in the collection, analyses, or interpretation of data; in the writing of the manuscript, and in the decision to publish the results.

\section{AUTHORS' CONTRIBUTIONS}

All authors contributed equally for the preparing of the manuscript. All authors critically revised the manuscript and approved of the final version.

\section{REFERENCES}

AĞIR, H. B. et al. Risk sources encountered by farmers in the open field production of strawberry and risk management strategies: a case of Menemen - Emiralen District of Izmir. Journal of Agricultural Sciences, v.21, n.2, p.13-25, 2015. Available from: $<$ https://dergipark.org.tr/tr/pub/ankutbd/issue/1937/24787>. Accessed: Mar. 23, 2020. doi: 10.15832/tbd.29197.

AĞIR, H. B.; AKBAY, C. Economic analysis of conctracted and non-contracted beef cattle farms in adana province. Gaziosmanpaşa Üniversitesi Ziraat Fakültesi Dergisi, v.34, n.3, p.139-147, 2017. Available from: <http://ziraatdergi.gop.edu. tr/Makaleler/653352266_139-147.pdf>. Accessed: Feb. 26, 2020. doi: $10.13002 /$ jafag4348.

AHMAD, D. et al. Analysis of wheat farmers' risk perceptions and attitudes: evidence from Punjab, Pakistan. Natural Hazards, 
v.95, p.845-861, 2019. Available from: <https://link.springer.com/ article/10.1007/s11069-018-3523-5>. Accessed: Feb. 19, 2020. doi: 10.1007/s11069-018-3523-5.

AHSAN, D. A. Farmers' motivations, risk perceptions and risk management strategies in a developing economy: Bangladesh experience. Journal of Risk Research, v.14, n.3, p.325-349, 2011. Available from: <https://www.tandfonline.com/doi/abs/1 0.1080/13669877.2010.541558>. Accessed: Feb. 16, 2020. doi: $10.1080 / 13669877.2010 .541558$.

AKARACHANTACHOTE, N. et al. Cutoff threshold of variable importance in projection for variable selection. International Journal of Pure and Applied Mathematics, v.94, n.3, p.307-322, 2014. Available from: <https://ijpam.eu/contents/2014-94-3/2/2. pdf $>$. Accessed: Aug. 3, 2020. doi: 10.12732/ijpam.v94i3.2.

AKCAOZ, $\mathrm{H}$. et al. Risk management strategies in dairy farming: A case study in Turkey. Journal of Animal and Veterinary Advances, v.8, n.5, p.949-958, 2009a. Available from: <https:// doi.org/10.3923/javaa.2009.949.958>. Accessed: Jan. 15, 2017. doi: $10.3923 /$ javaa.2009.949.9585.

AKCAOZ, $\mathrm{H}$. et al. Risk management and sustainability in banana production: A case study from Turkey, Journal of Food, Agriculture \& Environment, v.7, n.2, p.283-294, 2009b Available from: <http://apps.webofknowledge.com/full_record. 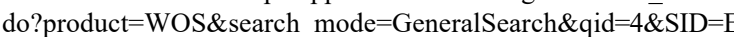 3XwaWih8nkwo9fT8Ua\&page=1\&doc=1>. Accessed: Mar. 15, 2017.

ALBEZ, A. Red Meat Sector Profitability and Cost Analysis in Erzurum Scale. Atatürk Üniversitesi Sosyal Bilimler Enstitüsü Dergisi, v.22, n.Special Issue, p.2969-2986, 2018. Available from: <https://dergipark.org.tr/tr/download/article-file/622421>. Accessed: Feb. 16, 2020.

ALPAR, R. Uygulamalı çok değişkenli istatistiksel yöntemler (3. Baskı). Ankara: Detay Yayıncılık, 2011.

ANONYMOUS. Erzurum agriculture strategy document (2014 - 2017), T. C. Ministry of Agriculture and Food, Erzurum (in Turkish), 2014.

ANONYMOUS (2020). Strategic plan 2020 - 2024, Erzurum Metropolitan Municipality, Erzurum (in Turkish), 2020.

BENNETT, R. The 'direct costs' of livestock disease: the development of a system of models for the analysis of 30 endemic livestock diseases in Great Britain. Journal of Agricultural Economics, v.54, n.1, p.55-71, 2003. Available from: $<$ https://onlinelibrary.wiley.com/doi/ abs/10.1111/j.1477-9552.2003.tb00048.x>. Accessed: Apr. 16, 2020. doi: $10.1111 /$ j.1477-9552.2003.tb00048.x.

BISHU, K. G., et al. Cattle farmers' perceptions of risk and risk management strategies: evidence from Northern Ethiopia, Journal of Risk Research, v.21, n.5, p.579-598, 2018. Available from: <https://doi.org/10.1080/13669877.2016.1223163>. Accessed: Aug. 18, 2019. doi: 10.1080/13669877.2016.1223163.

BREUSCH, T.; PAGAN, A. A Simple Test for Heteroscedasticity and Random Coefficient Variation. Econometrica, v.47, n.5, p.1287-1294, 1979. Available from: <https://www.jstor.org/ stable/1911963>. Accessed: Apr. 12, 2020. doi: 10.2307/1911963.

CRONBACH, L. F. Coefficient alpha and the internal structure of tests. Psychometrika, v.16, n.3, p.297-334, 1951. Available from:
$<$ https://doi.org/10.1007/BF02310555>. Accessed: Feb. 18, 2017. doi: $10.1007 / \mathrm{BF} 02310555$.

ÇELIK, C.; SARIÖZKAN, S. Economic Analysis of Cattle Fattening Enterprises in the Centre of Kırşehir Province. Harran Üniversitesi Veteriner Fakültesi Dergisi, v.6, n.1, p.38-45, 2017. Available from: $\quad<$ https://dergipark.org.tr/tr/download/articlefile/320839>. Accessed: Apr. 17, 2020.

DINLER, Z. Agricultural economy (Seventh edition). Ekin Basım Yayım ve Dağıtım, Bursa. (in Turkish), 2014.

E SAQIB, S. et al. Factors influencing farmers' adoption of agricultural credit as a risk management strategy: The case of Pakistan. International Journal of Disaster Risk Reduction, v.17, p.67-76, 2016. Available from: <https://www.sciencedirect. com/science/article/abs/pii/S2212420916300449>. Accessed: Apr. 07, 2020. doi: 10.1016/j.ijdrr.2016.03.008.

FLATEN, O. Comparing risk perceptions and risk management in organic and conventional dairy farming: empirical results from Norway. Livestock Production Science, v.95, n.1-2, p.11-25, 2005. Available from: <https://www.sciencedirect.com/science/ article/abs/pii/S030162260400288X>. Accessed: Apr. 07, 2020. doi: 10.1016/j.livprodsci.2004.10.014.

GÖKGÖZ, H. Risk perception and behaviors in livestock sector: case in the city of Afyonkarahisar. Afyon Kocatepe University, Institute of Social Sciences, Department of Business Administration, Afyonkarahisar, Turkey. (in Turkish with an abstract in English), 2018.

GÖZENER, B.; SAYILI, M. Production Cost and Factors Affecting Live Weight Gain in Cattle Fattening in the Turhal District of Tokat Province. Journal of Agricultural Sciences, v.21, n.2, p.288-299, 2015. Available from: <https://dergipark.org.tr/tr/pub/ankutbd/ article/25120>. Accessed: Apr. 09, 2020. doi: 10.15832/tbd.89331.

GREENE, W. Econometic analysis (3. edition), Prentice Hall International, New Jersey, 1997.

GUJARATI, D.N. Basic econometrics, Tata McGraw-Hill Education, 2009.

HAIR, F.J. et al. Multivariate data analysis, McMillan Publishing Company. 3rd Edition, New York, 1994.

HALL, D. C. et al. Analysis of Beef Producers' Risk Management Perceptions and Desire for Further Risk Management Education. Review of Agricultural Economics, v. 25, n.2, p.430-448, 2003. Available from: <https://www.jstor.org/stable/1349847>. Accessed: Mar. 09, 2020. doi: 10.2307/1349847.

HAYRAN, S. Perceptions of wheat producers towards risk and risk management strategies: A case study from Turkey. Ciência Rural, v.49, n.12, p.e20190396, 2019. Available from: <https:// www.scielo.br/scielo.php? script=sci_arttext\&pid $=$ S010384782019001200201\&lng=en\&nrm=iso\&tlng=en>. Accessed: Mar. 08, 2020. doi: 10.1590/0103-8478cr20190396.

HAYRAN, S.; GUL, A. Risk perception and management strategies in dairy farming: a case of Adana Province of Turkey. Turkish Journal of Agriculture - Food Science and Technology, v.3, n.12, p.952-961, 2015. Available from: <https://doi.org/10.24925/ turjaf.v3i12.952-961.583>. Accessed: Jul. 3, 2017. doi: 10.24925/ turjaf.v3i12.952-961.583. 
KALAYCI, SS. SPSS Applied Multivariate Statistics Techniques, Asil Yayın Dağıtım, İstanbul. (in Turkish), 2008.

KISAKA-LWAYO, M.; OBI, A. Risk perceptions and management strategies by smallholder farmers in KwaZulu-Natal Province, South Africa. International Journal of Agricultural Management, v.1, n.3, p.28-39, 2012. Available from: <https:// ideas.repec.org/a/ags/ijameu/149748.html\#download>. Accessed: Mar. 18, 2020. doi: 10.22004/ag.econ.149748.

LITRE, G.; BURSZTYN, M. Climatic and socio-economic risks perceptions and adaptation strategies among livestock family farmers in the Pampa Biome. Ambiente \& Sociedade, v.18, n.3, p.55-80, 2015. Available from: <https://www.scielo. br/scielo.php?pid=S1414-53X2015000300005\&script $=$ sci arttext\&tlng=en $>$. Accessed: Mar. 09, 2020. doi: 10.1590/1809-4422ASOC668V1832015.

MERANER, M.; FINGER, R. Risk perceptions, preferences and management strategies: evidence from a case study using German livestock farmers. Journal of Risk Research, v.22, n.1, p.1-26, 2019. Available from: <https://www.tandfonline.com/doi/abs/10 .1080/13669877.2017.1351476>. Accessed: Jan. 09, 2020. doi: 10.1080/13669877.2017.1351476.

MEUWISSEN, M. Perceptions of risks and risk management strategies; an analysis of Dutch livestock farmers. 1999 Annual meeting, August 8-11, Nashville, TN 21507, American Agricultural Economics Association (New Name 2008: Agricultural and Applied Economics Association), 1999, Available from: <https:// ageconsearch.umn.edu/record/21507>. Accessed: Jan. 19, 2020. doi: 10.22004/ag.econ. 21507 .

MEUWISSEN, M. P. M. Risk and risk management: an empirical analysis of Dutch livestock farmers. Livestock Production Science. v.69, n.1, p.43-53, 2001. Available from: <https://www.sciencedirect.com/science/article/abs/pii/ S0301622600002475>. Accessed: Jan. 11, 2020. doi: 10.1016/ S0301-6226(00)00247-5.

NADEZDA, J. et al. Risk factors in the agriculture sector. Agric. Econ.-Czech, v.63, n.6, p.247-258, 2017. Available from: <https:// www.agriculturejournals.cz/web/agricecon.htm?volume $=63 \&$ first Page $=247 \&$ type $=$ publishedArticle $>$. Accessed: Jan. 11, 2020. doi: 10.17221/212/2016-AGRICECON.
OECD (2019). Available from: <https://data.oecd.org/agroutput/ meat-consumption.htm $>$. Accessed: Apr. 01, 2020.

OTT, S. L. Measuring the national economic benefits of reducing livestock mortality. Preventive Veterinary Medicine. v.24, n.3, p.203-211, 1995. Available from: $<$ https://www.sciencedirect.com/ science/article/pii/016758779500477E $>$. Accessed: Jan. 11, 2020. doi: 10.1016/0167-5877(95)00477-E.

ÖZ, K.; KIZILASLAN, N. The Role of Agricultural Credit Cooperatives in Cattle Breeding: A Study on Sinop Erfelek. Gaziosmanpaşa Bilimsel Araştırma Dergisi. (in Turkish with an abstract in English). v.8, n.1, p.74-90, 2019. Available from: $<$ https://dergipark.org.tr/tr/pub/gbad/issue/43524/537048>. Accessed: Jan. 02, 2020.

ÖZSAYIN, D. Determining of Risk Sources and Risk Management Strategies in Dairy Farms: A Case of Çanakkale Province. Journal of Agricultural Sciences, v.25, n.3, p.272-280, 2019. Available from: <https://dergipark.org.tr/tr/pub/ankutbd/issue/48504/405335>. Accessed: Jan. 02, 2020. doi: 10.15832/ankutbd.405335.

ŞANAL A (2013). Efficiency analysis of cattle-breeding farms district of Erzurum, Turkey. Ataturk University, Graduate School of Natural and Applied Sciences, Department of Agricultural Economics, Erzurum, Turkey. (in Turkish with an abstract in English). 2013,

TÜİK (2020). Available from: < http://www.tuik.gov.tr/PreTablo. do?alt_id=1059>. Accessed: Feb. 27, 2020.

ÜNAL, Ç. Stock-Breeding Potential(ity) of Erzurum. Doğu Coğrafya Dergisi, (in Turkish with an abstract in English). v.9, n.12, p.257-274, 2004. Available from: <https://dergipark.org.tr/tr/ pub/ataunided/issue/2433/30915>. Accessed: Jan. 02, 2020.

ÜNVER, Ö.; GAMGAM, H. Applied basic statistical methods, Seçkin Yayıncılık, Ankara. (in Turkish), 2008.

WHITE, C.; BLACK, A. Costs and Benefits of Diversification: Whole farm case studies. RIRDC Publication, 2002. Available from: $\quad<$ https://www.agrifutures.com.au/wp-content/uploads/ publications/02-029.pdf $>$. Accessed: Jan. 5, 2020.

YAMANE, T. Elementary Sampling Theory. Englewood Cliffs, New Jersey: Prentice-Hall, Inc., 1967. 